\title{
Effects of the use of fiscal policy of incentive to innovation in performance of brazilian companies
}

\author{
Efeitos do uso da política fiscal de incentivo à inovação no \\ desempenho de empresas brasileiras
}

\author{
Itzhak David Simão Kaveski ${ }^{1,2}$ (D), lago França Lopes ${ }^{3}$ (D), Ilse Maria Beuren ${ }^{1}$ (D) \\ ${ }^{1}$ Universidade Federal de Santa Catarina - UFSC, Programa de Pós-graduação em Contabilidade, Florianópolis, \\ SC, Brasil. E-mail: itzhak.konoha@gmail.com; ilse.beuren@gmail.com \\ ${ }^{2}$ Universidade Federal de Mato Grosso do Sul - UFMS, Corumbá, MS, Brasil \\ ${ }^{3}$ Universidade Federal de Santa Catarina - UFSC, Florianópolis, SC, Brasil. E-mail: iagofrancalopes@gmail.com
}

How to cite: Kaveski, I. D. S., Lopes, I. F., \& Beuren, I. M. (2020). Effects of the use of fiscal policy of incentive to innovation in performance of brazilian companies. Gestão \& Produção, 27(1), e3832.

https://doi.org/10.1590/0104-530X3832-20

\begin{abstract}
The literature has some empirical evidence of the effects of fiscal incentives to increase private investment in innovation. Thus, this study aims to analyze the effects of the use of fiscal policy of incentive to innovation in performance of Brazilian companies listed on the Brasil Bolsa Balcão (B3). The research population comprised 494 companies and the sample was different for each performance variable, alternating between 221 and 251 companies. The accounting and market values of the period from 2006 to 2014 were used as performance parameters of the companies, and the use of fiscal policy of incentive to innovation was operationalized with a dummy variable. The data were analyzed by means of logistic regression. The results related to the accounting indicators show that the ROA, ROCE and ROE are positively and significantly related to the Innovation Incentive Tax Policy. While these measures may encourage companies to increase investments in Research, Development \& Innovation (RD\&I), they create distortions between companies and sectors because of the effects of these unsubsidized measures. As for the results related to market indicators no significant relationships were found. These results show that government actions and the posture of companies to make their RD\&I practices less costly are still not captured by the market. It is concluded that the use of fiscal policy of incentive to innovation is reflected in the performance of the companies surveyed in the analyzed period, which is partly explained by the fact that they are allowed to deduct investments in RD\&l in the tax base.
\end{abstract}

Keywords: Fiscal Policy of Incentive to Innovation; Research; Development \& Innovation; Performance.

Resumo: A literatura dispõe de algumas evidências empíricas dos efeitos de incentivos fiscais para aumentar o investimento privado em inovação. Assim, este estudo objetiva analisar os efeitos do uso da política fiscal de incentivo à inovação no desempenho de empresas brasileiras listadas na Brasil Bolsa Balcão (B3). A população da pesquisa compreendeu 494 empresas e a amostra apresentou-se diferente para cada variável de desempenho, alternando-se entre 221 e 251 empresas. Como parâmetros de desempenho das empresas utilizaram-se valores contábeis e de mercado do período de 2006 a 2014, já o uso da política fiscal de incentivo à inovação foi operacionalizada com uma variável dummy. Os dados foram analisados por meio

Received Feb. 26, 2017 - Accepted Sep. 30, 2017

Financial support: None.

This is an Open Access article distributed under the terms of the Creative Commons Attribution License, which permits unrestricted use, distribution, and reproduction in any medium, provided the original work is properly cited. 
de regressão logística. Os resultados relativos aos indicadores contábeis demonstram que o ROA, ROCE e ROE estão positivamente e significativamente relacionados com a Política Fiscal de Incentivo à Inovação. Embora estas medidas possam incentivar as empresas a aumentar investimentos em Pesquisa, Desenvolvimento \& Inovação (PD\&I), elas criam distorções entre empresas e setores devido aos efeitos destas medidas não-subsidiadas. Já nos resultados relativos aos indicadores de mercado não foram encontradas relações significativas. Esses resultados revelam que as ações governamentais e a postura das empresas para tornar menos onerosas suas práticas de PD\&I ainda não são captadas pelo mercado. Conclui-se que o uso da política fiscal de incentivo à inovação se reflete no desempenho das empresas pesquisadas no período analisado, o que se explica em parte pelo fato de lhes ser permitida a dedução dos investimentos em PD\&I na base tributária.

Palavras-chave: Política Fiscal de Incentivo à Inovação; Pesquisa; Desenvolvimento \& Inovação; Desempenho.

\section{Introduction}

Increasing corporate spending on Research, Development \& Innovation (RD\&I) is a challenge in developed and developing countries. Governments propose fiscal incentives to encourage companies to invest in RD\&I. With the systems of compensation to the companies' investments, fiscal incentives reduce the cost of RD\&I projects, making them attractive to companies (National Association of Research and Development of Innovative Companies, ANPEI, 2010). Although Brazil is the only Latin American country where innovation efforts exceed $1 \%$ of the Gross Domestic Product (GDP), this percentage is relatively smaller when compared to countries such as Israel (4.3\%), Finland (3.9\%) and South Korea (3.7\%) (Inter-American Development Bank - IDB, 2014).

Chaves \& Costa $(2016$, p. 2) mention that "Brazil has systematically sought to adopt innovation policies aimed at increasing corporate spending on RD\&l, adopting strategies to stimulate innovation seeking to increase the countries' competitiveness and economic development". These strategies are based on financing and/or economic subsidies, to share the risks of the innovative activity, through compensation of the amount spent by companies, for example, tax relief, which aim to boost private investment in RD\&I (ANPEI, 2010).

ANPEI (2010) points out that in Brazil companies have two main fiscal incentives for innovation: (i) fiscal incentives for RD\&l in any industrial sector, provided for in Chapter III of Law No. 11.196/2005 (Law of Good), regulated by Decree No. 5.798/2006, plus Law No. 11.487/2007, regulated by Decree No. 6.260/2007, and Law No. 11.774/2008, regulated by Decree No. 66.909/2009, and resulting legislation; and (ii) incentives for RD\&I in IT and the automation sector, provided for in Law 11.077/2004. In this study, the focus is on the first alternative, fiscal incentives for RD\&I in any industrial sector.

Although some studies, whether national (Chaves \& Costa, 2016) or international (Kim \& Yun, 1988; Montmartin \& Herrera, 2015), discuss the positive impact of the use of fiscal policies for innovation on business competitiveness, few address innovation as a basic premise for business development. Researches on fiscal policies of incentive for innovation are directed to: (i) evidencing how such governmental mechanism influences the organization; (ii) providing the manager with an alternative method of achieving the competitiveness of his products by saving resources; (iii) creating value for the organization through RD\&l; and (iv) showing their influence on the expansion of innovation projects, besides reinforcing the need for continuous improvement of the 
process as a key element of the organization's competitiveness (Lopes \& Beuren, 2016; Lopes et al., 2016).

Thus, a research gap is noticed, which identifies the extent to which the fiscal policy of incentive for innovation, provided for in Law no. 11.196/2005 (Law of Good) (Brasil, 2005) and resulting legislation, influences companies' performance. In this sense, this study intends to answer the following research question: What are the effects of the use of fiscal policy of incentive for innovation in the performance of Brazilian companies? Thus, the objective of the study is to analyze the effects of the use of fiscal policy of incentive for innovation in the performance of Brazilian companies listed in Brazil Bolsa Balcão (B3).

This study seeks to contribute in social and organizational perspectives. In the social perspective, this research seeks to promote discussions about the utility of fiscal incentives for innovation, while seeking to foster operational and cultural development of this practice in companies. In the organizational perspective, the research aims to show how the fiscal incentive for innovation can contribute to the companies' achievement of competitive advantages. In this way, it deals with a variable that is the result of a governmental fiscal policy and contributes to the discussions of its insertion in the organizational environment.

After a decade of Law of Good being in force, even with some insights on the positive impact of the use of fiscal policies for innovation in competitiveness, the number of companies that take advantage of this benefit is not very significant (Brasil, 2015). According to Piva (2013), although the Law of Good is presented as a stimulus for the development of research and technological innovation in the country, there is a legal uncertainty and a degree of subjectivity in the application of the legal concept of technological innovation and the whole framework required by it, even with the advent of Normative Instruction No. 1.187/2011 (Brasil, 2011), especially in view of the absence of administrative and judicial jurisprudence in this regard. It is also argued that managers know little about the benefits of fiscal policy to encourage innovation.

The study also intends to contribute to enlighten the trend observed in the literature of considering the fiscal policy of incentive for innovation as a dependent variable in empirical research. This research aims at repositioning the fiscal policy of incentive for innovation as an inductor and a receiver of environmental changes. Therefore, in this research organization is treated as part in the process of elaboration and improvement of fiscal policies, and also as the last stage of its execution, since the use of fiscal policy of incentive for innovation can influence the company's strategic decisions and ensure its continuity in the market.

\section{Literature review}

\subsection{Categories of innovation}

The role of innovation and knowledge for economic development has been recognized since the eighteenth century by Adam Smith, Karl Marx and Joseph Schumpeter and, since then, the relationship between wealth concentration and manufacturing technology has been examined, analyzing the conceptual and epistemological aspects of technological change, labor division and competition (Soly et al., 2014). From the organizational perspective, the innovation of a new product has the capacity to increase productivity and tends to generate increase in revenues. 
Likewise, a new method and a new source of raw material are elements that can alter the productivity and profitability of the companies. The success in a new organizational structure, besides influencing the highlighted items, results in gains in scale (Chaves \& Costa, 2016).

The scope of the concept of innovation is inferred from the foregoing. It goes from a new product or process to a new organizational structure or other technological innovation activity, such as innovations in marketing, business models or in the services provided by the company. Soly et al. (2014) state that the Frascati Manual, a document prepared by the Organization for Economic Co-operation and Development (OECD), used worldwide, including by the Ministry of Science Technology and Innovation of Brazil, as a reference for defining and delimiting the concepts of Research and Development, describes technological innovation as a set of "[...] scientific, technological, organizational, financial and commercial endeavors, including investment in new knowledge, which are carried out or are intended to lead to the realization of technologically new and better products and processes“ (OECD, 2013, p. 23).

Product innovation implies relevant changes in the potential of products and services, which includes new goods and services and even improvement of existing products (OECD, 2013). Two considerations deserve attention in this scope. First, the organization exposes itself to a risk, regarding market acceptance of the new product, and also whether it managed to capture the need demanded by the market. Second, creating value and giving creative power to managers and professionals involved in the RD\&I process, leading the organization to face the flexibility vs. control dilemma, in which the challenge is to keep the company flexible in order to generate ideas and, at the same time, not losing the control of resources and operations (Oyadomari et al., 2010).

The innovation of processes consists of new or significantly improved methods of production and distribution (OECD, 2013). This type of innovation can, for example, change the organization's supply chain. The benefits derived from this type of innovation usually result in increased productivity and/or quality of the final product and, mainly, the reduction of costs, which can be characterized as a competitive advantage.

Organizational innovations regard the implementation of new organizational methods, such as significant changes in the organization and in the inter-organizational relationship, with the purpose of improving the use of knowledge, the efficiency of workflows or the quality of goods or services (OECD, 2013). Based on the Economic Development Theory, organizational innovations aim at adjusting human and natural resources and using technology that result in development, as well as obtaining better organizational performance and competitive advantage (Vasconcelos \& Cyrino, 2000).

Marketing innovations aim at meeting the needs of consumers, through quality, the core feature of this process. They also involve the implementation of new or improved marketing methods to promote products or services (OECD, 2013). This type of innovation contemplates changes in product design and packaging, as well as methods of pricing goods and services (OECD, 2013).

\subsection{Fiscal Policy of Incentive for Innovation}

David et al. (2000) provide a conceptual framework when analyzing the different incentive channels and evidence that public policies influence corporate behavior regarding RD\&I investments. For these authors, in a simple framework, the investment in RD\&I is considered as an asset acquisition decision. According to Montmartin \& Herrera (2015), it is clear that direct tax subsidies or incentives reduce the marginal 
cost of RD\&I projects and provide incentives for companies to increase their levels of RD\&l investment.

In this scope, the triangulation between the role of credit, capital and money is characterized as a means to finance innovation and, consequently, economic development (Schumpeter, 1961). Thus, fiscal incentives appear as an alternative that seeks to balance private and public sector investments in RD\&I. Several countries make use of fiscal policies to encourage companies to invest in RD\&I (ANPEI, 2010). According to the OECD (2013), more than 25 countries use fiscal policies to stimulate RD\&l, including Brazil, China, Russia, South Africa, Argentina and Colombia.

Within the compensation systems of spending on RD\&l, fiscal incentives have the function of reducing the costs and risks of innovation projects, which makes them economically attractive to companies (ANPEI, 2010). According to Chaves (2016, p. 46), "[...] the cost of RD\&I is more sensitive to the fall of a tribute that is high in the company". For example, "[...] if a company has a high tax burden of Corporate Income $\operatorname{Tax}(\mathrm{CIT})$, the greater the offer of fiscal incentives that compensates its investments in RD\&I through CIT, the more stimulated the company will be to invest in RD\&l" (Chaves, 2016, p. 46). However, market imperfections and externalities are likely to have a strong modifying influence on the effects of such policies (Montmartin \& Herrera, 2015).

The economic literature on tax competition provides elements for assessing the external effects of fiscal incentives. Montmartin \& Herrera (2015) argue that the theoretical-practical contributions indicate that coordination among jurisdictions in the definition of budgetary policies is desirable when they concern activities that go beyond the limits of the interests of individual jurisdictions, because they generate externalities.

There is a consensus in the international literature on the ability of fiscal policies to encourage innovation to increase private investment in R\&D, although there are many approaches to this matter. Kim \& Yun (1988) assessed Korea's fiscal and spending policies over the period 1962-1985, with particular attention to its implications for the future. The results of the survey showed that, in the longer term, greater growth in social terms can be expected, as Korea will enter a more advanced stage of economic and social development.

David et al. (2000) identified different channels where the offer of government subsidies affects the companies' behavior, associating these effects with changes in companies' rate of return and the effects of these on the cost of marginal capital, or both situations. The results revealed that one-third of the cases investigated showed that the financing through RD\&l fiscal policy behaves as a substitute for RD\&l investments by the private sector.

Montmartin \& Herrera's (2015) research results present evidence on the effects of RD\&I subsidies and fiscal incentives on the intensity of the financing, from a database of 25 countries in the OECD, during the period from 1990 to 2009. Indeed, governments do not take spatial interdependencies into account in defining their R\&D policies, they tend to favor indirect rather than direct support, even if, in the long run, this choice is not the most effective.

Chaves \& Costa (2016) investigated whether the financial performance of companies listed in B3 is higher than those benefited by the Law of Good, from 2006 to 2012. The results indicated that encouraging private initiative to invest in RD\&l through fiscal incentives has resulted in direct benefits on companies' performance. This study reveals a research gap regarding the incorporation of market performance variables, to verify whether the results of technological innovation are perceived by it. 
It is inferred from the above that innovation over time represents an important part of the public and private agenda. It is noteworthy that each country seeks to encourage RD\&I through fiscal policies, but they are aligned with the country's legal, and even cultural, framework. According to Soly et al. (2014), in general terms, there are three mechanisms for achieving fiscal policy to encourage innovation: tax deduction, tax credit and accelerated or full depreciation. From this perspective, the Law of Good is discussed below.

\subsection{Law of good}

The 20th and 21st centuries were marked by the emergence of a legal framework to motivate companies to internally develop RD\&I activities (Garcia \& Bicalho, 2014). In Brazil, it was initiated by Decree Law No. 2.433/1988 (Brasil, 1988), revoked by Law No. 8.661/1993 (Brasil, 1993), which in Chapter III established the granting of tax benefits to companies that directly or indirectly carry out industrial technology activities in the country. In 2005, the Law of Good came into force (Law No. 11.196/2005) (Brasil, 2005), with a fiscal policy to encourage RD\&l, which made the development of technological innovation more attractive to companies. Chapter III of this Law deals with fiscal incentives, and revokes the mechanism of tax exemption provided for in articles 39 and 43 of Law No. 10.637/2002 (Garcia \& Bicalho, 2014). The Law of Good is regulated by Decree No. 5.798/2006 (Brasil, 2006).

Law No. 11.487 of June 15, 2007 (Brasil, 2007), amends Law No. 11.196 of November 21, 2005 (Brasil, 2005), to include a new incentive for technological innovation and to modify the rules regarding accelerated amortization for investments linked to research and development. Araújo (2010) points out that, in 2008, the Law of Good (Law No. 11.774/2008) was reviewed and the focus was on the incentive. The main change was that the companies could fully depreciate the good in the year of purchase and/or the investment in RD\&I for technological development.

In order to make technological innovation more attractive, Law No. 12.350, of December 20, 2010, revokes the income tax withholding (ITW) provided for in item V of Art. 17 of the Law of Good (Garcia \& Bicalho, 2014). Due to the absence of administrative and judicial jurisprudence in the application of the Law of Good, Normative Instruction No. 1,187 of November 21, 2011 (Brasil, 2011), disciplines the fiscal incentives of the activities of technological research and development of technological innovation, dealt with in Art. 17 to 26 of Law No. 11.196, of November 21, 2005 (Brasil, 2005).

Mendes et al. (2013) point out that there has been an evolution in the national spending on R\&D, both in the public and private sectors, after the validity of the Law on Innovation and the Law of Good. In the private sector, the spending favored by the Law of Good was increasing when analyzing the national spending on Science and Technology in relation to GDP, rising from $0.63 \%$ in 2006 to $0.72 \%$ in 2009 . As for the public sector, it went from $0.64 \%$ in 2006 to $0.84 \%$ in 2009 . According to the authors, from 2000 to 2009 the evolution of the national spending on R\&D in relation to the GDP was increasing. Lastly, private spending went from $0.49 \%$ in 2005 to $0.58 \%$ in 2009 , public spending went from $0.48 \%$ in 2005 to $0.61 \%$ in 2009 , period that the effects of the Innovation and Law of Good began.

MSTI (Brasil, 2015) recognizes that there is evidence of growth in the number of companies that have opted to adhere to Law of Good. Of the total of 1,206 participating companies in 2014 , only 215 were deemed not eligible to benefit from the fiscal policy. 
MSTI (Brasil, 2015) points out that in the base year 2014 they received 1,206 forms of companies participating in the fiscal incentives the Law of Good, an increase of $4.15 \%$ in relation to the base year 2013. The MSTI (Brasil, 2015) comments in its Annual Report on the Use of Fiscal incentives that, for the 1,206 companies that submitted projects to participate in fiscal incentives in the base year 2014, there records of investments in the order of $\mathrm{R} \$ 9.25$ billion, having tax exemptions in the order of $\mathrm{R} \$ 1.68$ billion.

In 2011, the Brazilian economy started to face a diffuse scenario (Silva \& Terra, 2012). This reflected in the investments in innovation in 2011 , which had a fall of $3.66 \%$ compared to 2010 . This result is also attributed to the promulgation of Normative Instruction No. 1.187, on August 29, 2011, which disciplined the fiscal incentives for technological research activities and the development of technological innovation, dealt with in Art. 17 to 26 of the Law of Good (Garcia \& Bicalho, 2014). Data from 2014, of the MSTI, show that the companies' investments in RD\&I in the base year of 2014, in relation to GDP Brazil, reached $0.15 \%$. To achieve the goal of $1.8 \%$ of GDP Brazil of investment in Research, Development and Innovation (goal of the National Strategy for Science, Technology and Innovation - NSSTI for the base year of 2014), there are more efforts to be made regarding private and public participation (Brasil, 2015).

Brazil has become an important actor in the generation of innovation. The number of researchers hired since the Law of Good came into force emphasizes that increasing investments must be made in attractiveness that allows the country to join the map of global innovation (Calmanovici, 2011). However, according to Zittei et al. (2016, p. 2939), "[...] despite the annual growth in the number of companies that use the benefit, compared to the number of companies in Brazil this amount is low, due to limitations imposed by the Law of Good". According to these authors, the main limitations are in the taxation requirement for Real Profit and the need to measure the profits of the year base, since most Brazilian companies are governed by the National Simplified Taxation System or by the Presumed Profit, only a small part is taxed by the Real profit systematic.

\section{Methodological procedures}

This descriptive study, with quantitative nature, was carried out based on documentary research, having as population the companies listed in Brazil Bolsa Balcão (B3), which are required to disclose their accounting information, allowing the access to data necessary for the development of the study. Thus, the population of this study is composed of the 494 listed companies. A possible republishing of the financial statements and the updating of the data after the month of August 2016, date on which the data collection was finalized, was not considered. Table 1 shows the number of companies of the population and of the sample, classified according to their economic sector.

Table 1. Population and sample of the research.

\begin{tabular}{lcccc}
\hline \multicolumn{5}{c}{ Panel A - ROA } \\
\hline B3 Economic segments & Pop. & \% of the Population & Sample & \% of the Sample \\
\hline Industrial Goods & 79 & 15.99 & 51 & 20.40 \\
\hline Cyclic Consumption & 89 & 18.02 & 77 & 30.80 \\
\hline Non-Cyclic Consumption & 28 & 5.67 & 21 & 8.40 \\
\hline
\end{tabular}




\begin{tabular}{|c|c|c|c|c|}
\hline Financial and Others & 136 & 27.53 & 0 & 0.00 \\
\hline Basic Materials & 35 & 7.09 & 29 & 11.60 \\
\hline Non-Classified & 17 & 3.44 & 0 & 0.00 \\
\hline Petrol, Gas and Biofuels & 11 & 2.23 & 9 & 3.60 \\
\hline Health & 13 & 2.63 & 11 & 4.40 \\
\hline Information Technology & 9 & 1.82 & 6 & 2.40 \\
\hline Telecommunications & 7 & 1.42 & 5 & 2.00 \\
\hline Public Utility & 70 & 14.17 & 41 & 16.40 \\
\hline Total & 494 & $100 \%$ & 250 & $100 \%$ \\
\hline \multicolumn{5}{|c|}{ Panel B - ROCE } \\
\hline B3 Economic segments & Pop. & $\%$ of the Population & Sample & $\%$ of the Sample \\
\hline Industrial Goods & 79 & 15.99 & 46 & 19.74 \\
\hline Cyclic Consumption & 89 & 18.02 & 67 & 28.76 \\
\hline Non-Cyclic Consumption & 28 & 5.67 & 20 & 8.58 \\
\hline Financial and Others & 136 & 27.53 & 0 & 0.00 \\
\hline Basic Materials & 35 & 7.09 & 28 & 12.02 \\
\hline Non-Classified & 17 & 3.44 & 0 & 0.00 \\
\hline Petrol, Gas and Biofuels & 11 & 2.23 & 9 & 3.86 \\
\hline Health & 13 & 2.63 & 11 & 4.72 \\
\hline Information Technology & 9 & 1.82 & 6 & 2.58 \\
\hline Telecommunications & 7 & 1.42 & 5 & 2.15 \\
\hline Public Utility & 70 & 14.17 & 41 & 17.60 \\
\hline Total & 494 & $100 \%$ & 233 & $100 \%$ \\
\hline \multicolumn{5}{|c|}{ Panel C - ROE } \\
\hline B3 Economic segments & Pop. & $\%$ of the Population & Sample & $\%$ of the Sample \\
\hline Industrial Goods & 79 & 15.99 & 49 & 20.16 \\
\hline Cyclic Consumption & 89 & 18.02 & 75 & 30.86 \\
\hline Non-Cyclic Consumption & 28 & 5.67 & 19 & 7.82 \\
\hline Financial and Others & 136 & 27.53 & 0 & 0.00 \\
\hline Basic Materials & 35 & 7.09 & 29 & 11.93 \\
\hline Non-Classified & 17 & 3.44 & 0 & 0.00 \\
\hline Petrol, Gas and Biofuels & 11 & 2.23 & 8 & 3.29 \\
\hline Health & 13 & 2.63 & 11 & 4.53 \\
\hline Information Technology & 9 & 1.82 & 6 & 2.47 \\
\hline Telecommunications & 7 & 1.42 & 5 & 2.06 \\
\hline Public Utility & 70 & 14.17 & 41 & 16.87 \\
\hline Total & 494 & $100 \%$ & 243 & $100 \%$ \\
\hline \multicolumn{5}{|c|}{ Panel D - MTB } \\
\hline B3 Economic segments & Pop. & $\%$ of the Population & Sample & $\%$ of the Sample \\
\hline Industrial Goods & 79 & 15.99 & 44 & 19.91 \\
\hline Cyclic Consumption & 89 & 18.02 & 68 & 30.77 \\
\hline Non-Cyclic Consumption & 28 & 5.67 & 20 & 9.05 \\
\hline Financial and Others & 136 & 27.53 & 0 & 0.00 \\
\hline Basic Materials & 35 & 7.09 & 25 & 11.31 \\
\hline Non-Classified & 17 & 3.44 & 0 & 0.00 \\
\hline Petrol, Gas and Biofuels & 11 & 2.23 & 9 & 4.07 \\
\hline
\end{tabular}




\begin{tabular}{|c|c|c|c|c|}
\hline Health & 13 & 2.63 & 9 & 4.07 \\
\hline Information Technology & 9 & 1.82 & 6 & 2.71 \\
\hline Telecommunications & 7 & 1.42 & 5 & 2.26 \\
\hline Public Utility & 70 & 14.17 & 35 & 15.84 \\
\hline Total & 494 & $100 \%$ & 221 & $100 \%$ \\
\hline \multicolumn{5}{|c|}{ Panel E - Tobin's Q } \\
\hline B3 Economic segments & Pop. & $\%$ of the Population & Sample & $\%$ of the Sample \\
\hline Industrial Goods & 79 & 15.99 & 51 & 20.32 \\
\hline Cyclic Consumption & 89 & 18.02 & 77 & 30.68 \\
\hline Non-Cyclic Consumption & 28 & 5.67 & 22 & 8.76 \\
\hline Financial and Others & 136 & 27.53 & 0 & 0.00 \\
\hline Basic Materials & 35 & 7.09 & 29 & 11.55 \\
\hline Non-Classified & 17 & 3.44 & 0 & 0.00 \\
\hline Petrol, Gas and Biofuels & 11 & 2.23 & 9 & 3.59 \\
\hline Health & 13 & 2.63 & 11 & 4.38 \\
\hline Information Technology & 9 & 1.82 & 6 & 2.39 \\
\hline Telecommunications & 7 & 1.42 & 5 & 1.99 \\
\hline Public Utility & 70 & 14.17 & 41 & 16.33 \\
\hline Total & 494 & $100 \%$ & 251 & $100 \%$ \\
\hline
\end{tabular}

Source: Research data.

The number of elements of the sample was different for each performance variable, because it was initially considered that each company had to have the information of each indicator. Subsequently, those companies that did not disclose the information related to the control variables of the study were eliminated, constituting a different sample for each one of the performance indicators.

Regarding the measurement and operationalization of the variables of interest, Chart 1 shows the variables related to the economic-financial and market performance and to the use of fiscal incentives of the Brazilian companies in the research sample, in addition to the control variables.

Chart 1. Variables used in the study.

\begin{tabular}{|c|c|c|}
\hline & Variables & Proxy \\
\hline \multirow{5}{*}{ Independent } & Return on Total Assets (ROA) & $R O A=\frac{\text { Net profit }}{\text { Total Asset }}$ \\
\hline & $\begin{array}{l}\text { Return on Capital Employed } \\
\text { (ROCE) }\end{array}$ & ROCE $=\frac{P B I I T}{\text { Capital Employed }}$ \\
\hline & Return on Equity (ROE) & $R O E=\frac{\text { Net Profit }}{\text { Net equity }}$ \\
\hline & Market-to-Book (MTB) & MTB $=\frac{\text { Market Value }}{\text { BookValue }}$ \\
\hline & Tobin's $Q(Q)$ & $Q=\frac{\text { Market Value }+ \text { Debts }}{\text { Total Asset }}$ \\
\hline Dependent & $\begin{array}{l}\text { Fiscal Policy of Incentive for } \\
\text { innovation (INC) }\end{array}$ & $\begin{array}{l}\text { Dummy variable, } 1 \text { when company } \\
\text { uses the fiscal policy of incentive for } \\
\text { innovation, } 0 \text { otherwise. }\end{array}$ \\
\hline
\end{tabular}




\begin{tabular}{|c|c|c|}
\hline \multicolumn{2}{|c|}{ Variables } & Proxy \\
\hline \multirow{4}{*}{ Control } & Company Size (SCI) & $=$ Total asset logarithm \\
\cline { 2 - 3 } & Growth Opportunity (GRO) & $=\%$ Variation of Net Revenue \\
\cline { 2 - 3 } & Total book value of debt (TVD) & $\begin{array}{c}\text { Current liabilities + Long-term } \\
\text { liabilities) / Total Asset }\end{array}$ \\
\cline { 2 - 3 } & Market value (MV) & Natural logarithm of market value. \\
\hline
\end{tabular}

Source: Prepared by the author.

The data collected refer to the period from 2006 to 2014 . This time cut is initially justified under the normative aspect, since in 2006 Law 11.196, of November 21, 2005 (Law of Good) (Brasil, 2005) came into force. At the other extreme, the year 2014 was the last year in which the Annual Report on the Use of Fiscal Incentives of the Ministry of Science, Technology and Innovation (MSTI) (Brasil, 2015) was available at the time of the collection of data.

Descriptive statistics and the Mann-Whitney mean test were applied to the data collected to verify whether the dependent and control variables are the equal or different in companies that use fiscal policy of incentive for innovation and those that do not. Subsequently, Pearson's correlation and Variance Inflation Factor (VIF) were applied to verify the multicollinearity problems between the variables. Finally, Panel Data Logistic Regression was applied.

The statistical technique of Panel Data Logistic Regression was used because, according to Fávero $(2015$, p. 261), when the data "[...] vary among individuals and over time, but the dependent variable presents qualitative data with dichotomous values [...], we must approach the problem through non-linear regression models for panel data". Five panel data models were applied to verify the effects of the fiscal policy of incentive for innovation in the performance of Brazilian companies listed in $B 3$, is expressed in Equation 1:

$$
Y_{i, t}=\beta_{0}+\beta_{1} P E R_{i, t}+\beta_{2} C S I_{i, t}+\beta_{3} G R O_{i, t}+\beta_{4} T V D_{i, t}+\beta_{5} M V_{i, t}+\varepsilon_{i, t}
$$

$Y$ indicates Fiscal Policy for Incentive for innovation (INC). The explanatory variable of Performance (PER) of the company was measured by five measures of performance, based both on the accounting and the market. The first three represent measures of accounting performance, including Total Return on Assets (ROA), Return on Capital Employed (ROCE) and Return on Equity (ROE). The market measure comprises Market-to-Book (MTB) and Tobin's Q (Q). Other characteristics of the company were considered as measures that affect the use of INC, included as control variables in the panel data model. These control variables consist of company size (CSI), growth opportunity (GRO), total book value of debt (TVD) and market value (MV).

\section{Description and analysis of results}

Table 2 presents the descriptive analysis of the variables of the study, in addition to the mean test, segregated by those companies that make use of fiscal policy to encourage innovation and those that don't. 
Table 2. Descriptive statistics and mean tests.

\begin{tabular}{|c|c|c|c|c|c|c|c|c|}
\hline Variable & INC & $\mathbf{N}$ & Maximum & Minimum & Mean & $\begin{array}{l}\text { Standard } \\
\text { Deviation }\end{array}$ & $\begin{array}{c}\text { Mann- } \\
\text { Whitne } \\
y\end{array}$ & Sig. \\
\hline \multicolumn{9}{|l|}{$\begin{array}{c}\text { Panel A - } \\
\text { ROA }\end{array}$} \\
\hline \multirow{2}{*}{ ROA } & Yes & 331 & 42.561 & -51.784 & 7.935 & 6.925 & \multirow{2}{*}{-13.052} & \multirow{2}{*}{0.000} \\
\hline & No & 1,493 & $1,188.856$ & $-4,633.359$ & -9.383 & 170.321 & & \\
\hline \multirow{2}{*}{ CSI } & Yes & 331 & 8.491 & 4.859 & 6.459 & 0.661 & \multirow{2}{*}{-6.409} & \multirow{2}{*}{0.000} \\
\hline & No & 1,493 & 8.269 & 3.691 & 6.125 & 0.785 & & \\
\hline \multirow{2}{*}{ GRO } & Yes & 331 & 936.860 & $-1,130.164$ & 0.927 & 108.419 & \multirow{2}{*}{-3.176} & \multirow{2}{*}{0.001} \\
\hline & No & 1,493 & $2,671.647$ & $-3,442.400$ & 6.034 & 144.144 & & \\
\hline \multirow{2}{*}{ TVD } & Yes & 331 & 335.397 & 11.843 & 57.218 & 23.314 & \multirow{2}{*}{-3.695} & \multirow{2}{*}{0.000} \\
\hline & No & 1,493 & $48,722.396$ & 1.135 & 169.346 & $1,621.609$ & & \\
\hline \multirow{2}{*}{ MV } & Yes & 331 & 19.432 & 10.737 & 14.635 & 1.598 & \multirow{2}{*}{-10.170} & \multirow{2}{*}{0.000} \\
\hline & No & 1,493 & 19.416 & 5.568 & 13.344 & 2.068 & & \\
\hline \multicolumn{9}{|l|}{$\begin{array}{l}\text { Panel B - } \\
\text { ROCE }\end{array}$} \\
\hline \multirow{2}{*}{ ROCE } & Yes & 328 & 311.530 & -249.217 & 20.027 & 28.345 & \multirow{2}{*}{-11.798} & \multirow{2}{*}{0.000} \\
\hline & No & 1,321 & $53,242.802$ & $-6,357.421$ & 29.305 & $1,486.757$ & & \\
\hline \multirow{2}{*}{ CSI } & Yes & 328 & 8.491 & 4.859 & 6.470 & 0.654 & \multirow{2}{*}{-4.132} & גת \\
\hline & No & 1,321 & 8.269 & 4.048 & 6.257 & 0.704 & & 0.000 \\
\hline GRO & Yes & 328 & 936.860 & $-1,130.164$ & 0.769 & 108.899 & -2536 & 0011 \\
\hline GRU & No & 1,321 & $2,549.641$ & $-3,442.400$ & 5.685 & 131.692 & -2.530 & 0.011 \\
\hline TY & Yes & 328 & 89.472 & 11.843 & 55.787 & 15.895 & O440 & 0660 \\
\hline TVD & No & 1,321 & 105.207 & 1.135 & 56.213 & 20.454 & -0.440 & 0.000 \\
\hline MV & Yes & 328 & 19.432 & 10.737 & 14.663 & 1.578 & -8003 & 0000 \\
\hline IVIV & No & 1,321 & 19.416 & 8.208 & 13.754 & 1.781 & -0.003 & 0.000 \\
\hline $\begin{array}{c}\text { Panel C - } \\
\text { ROE }\end{array}$ & & & & & & & & \\
\hline$R \cap F$ & Yes & 327 & 63.671 & -32.128 & 12.260 & 9.606 & 11724 & (200 \\
\hline RUE & No & 1,449 & 233.301 & $-9,323.927$ & -7.777 & 298.242 & $-11.1<4$ & 0.000 \\
\hline CSI & Yes & 327 & 8.491 & 4.859 & 6.462 & 0.665 & 6089 & - \\
\hline (ס) & No & 1,449 & 8.269 & 3.691 & 6.142 & 0.776 & -0.005 & 0.000 \\
\hline GRO & Yes & 327 & 936.860 & $-1,130.164$ & 0.439 & 108.802 & -3031 & (200 \\
\hline S & No & 1,449 & $2,549.641$ & $-3,442.400$ & 4.266 & 128.375 & -0.001 & 0.002 \\
\hline TV & Yes & 327 & 335.397 & 11.843 & 56.955 & 23.301 & 3172 & בחחת \\
\hline TVD & No & 1,449 & $48,722.396$ & 1.135 & 163.926 & $1,640.845$ & $-0.17<$ & 0.002 \\
\hline$M Y$ & Yes & 327 & 19.432 & 10.737 & 14.628 & 1.605 & -9 706 & > \\
\hline IVIV & No & 1,449 & 19.416 & 5.568 & 13.422 & 1.995 & -5.100 & 0.000 \\
\hline $\begin{array}{c}\text { Panel D - } \\
\text { MTB }\end{array}$ & & & & & & & & \\
\hline PTP & Yes & 278 & 28.795 & 0.302 & 3.133 & 3.772 & & \\
\hline DIID & No & 1,105 & 181.476 & -224.153 & 2.483 & 12.222 & -0.469 & 0.000 \\
\hline CSt & Yes & 278 & 8.491 & 4.859 & 6.520 & 0.639 & -4740 & ( \\
\hline Col & No & 1,105 & 8.269 & 3.691 & 6.244 & 0.746 & -4.140 & 0.000 \\
\hline GRO & Yes & 278 & 936.860 & $-1,130.164$ & 0.435 & 117.350 & 277 & ( \\
\hline GR & No & 1,105 & 507.334 & $-3,442.400$ & 2.033 & 113.885 & -2.174 & 0.000 \\
\hline TY & Yes & 278 & 89.472 & 11.843 & 55.162 & 16.370 & 4036 & (2000 \\
\hline IVD & No & 1,105 & $3,615.439$ & 1.135 & 76.955 & 144.897 & -4.030 & 0.000 \\
\hline MY & Yes & 278 & 19.432 & 10.737 & 14.845 & 1.485 & -8625 & > \\
\hline IVIV & No & 1,105 & 19.416 & 7.624 & 13.710 & 1.916 & $-0.0<v$ & 0.000 \\
\hline
\end{tabular}




\begin{tabular}{|c|c|c|c|c|c|c|c|c|}
\hline Variable & INC & $\mathbf{N}$ & Maximum & Minimum & Mean & $\begin{array}{l}\text { Standard } \\
\text { Deviation }\end{array}$ & $\begin{array}{c}\text { Mann- } \\
\text { Whitne } \\
y\end{array}$ & Sig. \\
\hline \multicolumn{9}{|l|}{$\begin{array}{l}\text { Panel E - } \\
\text { Tobin's Q }\end{array}$} \\
\hline \multirow{2}{*}{ Q } & Yes & 331 & 2914.400 & 0.585 & 299.784 & 207.630 & \multirow{2}{*}{-1.681} & \multirow{2}{*}{0.093} \\
\hline & No & 1,515 & $244,359.551$ & 0.130 & 781.698 & $8,163.642$ & & \\
\hline \multirow{2}{*}{ CSI } & Yes & 331 & 8.491 & 4.859 & 6.459 & 0.661 & \multirow{2}{*}{-6.525} & \multirow{2}{*}{0.000} \\
\hline & No & 1,515 & 8.269 & 3.691 & 6.118 & 0.788 & & \\
\hline \multirow{2}{*}{ GRO } & Yes & 331 & 936.860 & $-1,130.164$ & 0.927 & 108.419 & \multirow{2}{*}{-3.391} & \multirow{2}{*}{0.001} \\
\hline & No & 1,515 & $2,671.647$ & $-3,442.400$ & 5.954 & 143.094 & & \\
\hline \multirow{2}{*}{ TVD } & Yes & 331 & 335.397 & 11.843 & 57.218 & 23.314 & \multirow{2}{*}{-3.768} & \multirow{2}{*}{0.000} \\
\hline & No & 1,515 & $48,722.396$ & 1.135 & 168.868 & $1,609.946$ & & \\
\hline \multirow{2}{*}{ MV } & Yes & 331 & 19.432 & 10.737 & 14.635 & 1.598 & \multirow{2}{*}{-10.206} & \multirow{2}{*}{0.000} \\
\hline & No & 1,515 & 19.416 & 5.568 & 13.341 & 2.067 & & \\
\hline
\end{tabular}

Source: Research data.

According to Table 2, regarding the Return on Total Asset (ROA) index, companies had a negative index, both those that use policies of fiscal incentive for innovation and those that don't, indicating that there are companies in the sample which had losses in the two observations, that is, there are companies that are not able to generate profit and capitalize. However, the companies performed positively, exceeding their cost of capital. The significance of the Mann-Whitney test for the ROA indicates that, in the companies which use the INC, there is a better average of efficiency in generating profits from its assets, in comparison to those that do not use the INC. Besides, regarding the control variables, the mean test was significant for all of them, demonstrating that the CSI, GRO, TVD and MV are different between the companies that make use of the INC and those that don't, in this group of companies.

Return on Capital Employed (ROCE) was both positive and negative for both groups of companies (INC). This shows that some companies reported a profit before interest and income tax higher than the funds invested by shareholders and creditors in the business, while some companies presented losses. The significance of the Mann-Whitney test for the ROCE indicates that companies that didn't use the INC, on average, are able to pay their creditors and their shareholders and still have a financial slack. However, in this group of companies, ROCE was both higher $(53242,802)$, and lower $(-6357,421)$. The mean test was not significant only for the TVD variable, demonstrating that the companies that use the INC and those that do not use, for the ROCE group, did not show differences in their total indebtedness.

Regarding the Return on Equity (ROE), both for the companies that make use of the INC and for those that do not, companies presented a negative index. Thus, there are companies in which the shareholders are not having a return, but there are also companies that show high values in the ROE index. The significance of the Mann-Whitney test for ROE indicates that in the companies in which INC was used, on average, shareholders are having a greater return on the resources invested in the company. This reinforces the importance of the fiscal policy for the performance of the companies and for the shareholders. The control variables showed significant differences for the companies that use the INC and those that do not, in the ROE sample.

A Market-to-Book (MTB) disparity is observed between companies, both those that use INC and those that do not. Some companies had book value higher than market value, because their indicator was lower than 1 , which indicates that they are devalued 
in the market, while others are valued. The significance of the Mann-Whitney test for the MTB indicates that that companies that use INC, on average, are more valued in the market. However, the company that doesn't use the INC has the highest MTB $(181,476)$ in comparison to the company that uses it $(28,795)$, that is, the company with the highest market value doesn't need the Law of Good for this positioning. In addition to the highest MTB, it also had the lowest MTB $(-224,153)$. These variations may have contributed to the fact that companies that make use of the INC, on average, have a better MTB, since their lowest MTB was 0.302 . The control variables showed significant differences between the companies that use the INC and those that don't, in the MTB sample.

Finally, through the variable Tobin's $Q$, both the companies that use the INC and those that don't have their investments stimulated, because their capitals are more valued in the market than the costs to produce them. The significance of the Mann-Whitney test for Tobin's $Q$ should be considered parsimoniously, since it was significant at the level of $10 \%$, having little power to explain the differences between companies that use the INC for those that do not. It was found out that the companies that don't use the INC, on average, have their investments more stimulated, besides presenting a higher Tobin's $Q(244,359,551)$. The control variables showed significant differences between the companies that make use of the INC and those that don't, in the Tobin's $Q$ sample.

In order to verify whether the independent variable and the control variables are correlated among themselves and with the dependent ones, in addition to verifying whether there are no problems of multicollinearity, Table 3 presents the Pearson correlation and collinearity statistics.

Table 3. Pearson correlation and collinearity statistics.

\begin{tabular}{|c|c|c|c|c|c|c|c|c|}
\hline \multicolumn{7}{|c|}{ Pearson correlation } & \multicolumn{2}{|c|}{ Collinearity statistics } \\
\hline \multicolumn{9}{|c|}{ Panel A - ROA } \\
\hline Variables & ROA & INC & CSI & GRO & TVD & MV & Tolerance & VIF \\
\hline ROA & 1 & 0.043 & $0.150^{* *}$ & 0.005 & $-0.954^{\star *}$ & $0.143^{* *}$ & & \\
\hline INC & & 1 & $0.167^{\star *}$ & -0.014 & -0.029 & $0.243^{* *}$ & 0.935 & 1.069 \\
\hline CSI & & & 1 & -0.013 & $-0.159^{\star *}$ & $0.850^{* *}$ & 0.274 & 3.643 \\
\hline GRO & & & & 1 & 0.005 & -0.021 & 0.999 & 1.001 \\
\hline TVD & & & & & 1 & $-0.135^{\star *}$ & 0.975 & 1.026 \\
\hline MV & & & & & & 1 & 0.268 & 3.738 \\
\hline \multicolumn{9}{|c|}{ Panel B - ROCE } \\
\hline Variables & ROCE & INC & CSI & GRO & TVD & MV & Tolerance & VIF \\
\hline ROCE & 1 & -0.003 & -0.035 & 0.000 & 0.013 & -0.002 & & \\
\hline INC & & 1 & $0.122^{\star *}$ & -0.015 & -0.009 & $0.204^{* *}$ & 0.949 & 1.054 \\
\hline CSI & & & 1 & 0.007 & $0.161^{\star *}$ & $0.830^{* *}$ & 0.260 & 3.853 \\
\hline GRO & & & & 1 & -0.001 & 0.005 & 1.000 & 1.000 \\
\hline TVD & & & & & 1 & $-0.071^{* *}$ & 0.837 & 1.195 \\
\hline MV & & & & & & 1 & 0.258 & 3.874 \\
\hline \multicolumn{9}{|c|}{ Panel C - ROE } \\
\hline Variables & ROE & INC & CSI & GRO & TVD & MV & Tolerance & VIF \\
\hline ROE & 1 & 0.029 & 0.037 & 0.000 & $-0.115^{\star *}$ & $0.064^{* *}$ & & \\
\hline INC & & 1 & $0.162^{\star \star}$ & -0.012 & -0.028 & $0.235^{\star \star}$ & 0.939 & 1.065 \\
\hline CSI & & & 1 & 0.012 & $-0.154^{* *}$ & $0.848^{* *}$ & 0.277 & 3.604 \\
\hline GRO & & & & 1 & 0.003 & 0.010 & 1.000 & 1.000 \\
\hline
\end{tabular}




\begin{tabular}{|c|c|c|c|c|c|c|c|c|}
\hline \multicolumn{7}{|c|}{ Pearson correlation } & \multicolumn{2}{|c|}{ Collinearity statistics } \\
\hline TVD & & & & & 1 & $-0.133^{* *}$ & 0.976 & 1.024 \\
\hline MV & & & & & & 1 & 0.271 & 3.692 \\
\hline \multicolumn{9}{|c|}{ Panel D - MTB } \\
\hline Variables & MTB & INC & CSI & GRO & TVD & MV & Tolerance & VIF \\
\hline MTB & 1 & 0.024 & 0.043 & 0.001 & -0.019 & $0.097^{* *}$ & & \\
\hline INC & & 1 & $0.151^{* *}$ & -0.006 & $-0.067^{*}$ & $0.240^{* *}$ & 0.935 & 1.070 \\
\hline CSI & & & 1 & 0.001 & $-0.193^{* *}$ & $0.827^{\star *}$ & 0.313 & 3.194 \\
\hline GRO & & & & 1 & -0.018 & 0.009 & 0.999 & 1.001 \\
\hline TVD & & & & & 1 & $-0.259^{* *}$ & 0.931 & 1.074 \\
\hline MV & & & & & & 1 & 0.293 & 3.415 \\
\hline \multicolumn{9}{|c|}{ Panel E - Tobin's Q } \\
\hline Variables & $\begin{array}{c}\text { Tobin's } \\
Q\end{array}$ & INC & CSI & GRO & TVD & MV & Tolerance & VIF \\
\hline $\begin{array}{l}Q \text { de } \\
\text { Tobin }\end{array}$ & 1 & -0.025 & $-0.142^{* *}$ & 0.005 & $0.986^{* *}$ & $-0.120^{* *}$ & & \\
\hline INC & & 1 & $0.168^{* *}$ & -0.014 & -0.029 & $0.242^{\star *}$ & 0.936 & 1.068 \\
\hline TAM & & & 1 & -0.012 & $-0.158^{* *}$ & $0.848^{\star *}$ & 0.277 & 3.614 \\
\hline GRO & & & & 1 & 0.005 & -0.021 & 0.999 & 1.001 \\
\hline TVD & & & & & 1 & $-0.135^{\star *}$ & 0.975 & 1.026 \\
\hline MV & & & & & & 1 & 0.270 & 3.705 \\
\hline
\end{tabular}

Note: Significant correlation at ${ }^{*} 0.05$ and at ${ }^{* *} 0.01$. Source: Research data.

According to Table 3, the correlation matrix shows that the use of the Fiscal Policy of Incentive for innovation (INC) is not statistically correlated with the variables of accounting and market performance, since it was not significant. Such findings lead one to presume that the use of the INC does not affect the performance of the company. However, since it had a significant correlation with the other control variables, and these variables showed a correlation with the other performance variables, in the regression the use of the INC may influence the performance of the companies. However, such statement can only be considered from the logistic regression of panel data, since correlation only demonstrates an association between variables, not a cause and effect relationship.

Pearson correlation results indicate that there is not a high degree of correlation between the use of INC and the control variables (correlation higher than $85 \%$ ), that is, there are no high multicollinearity problems that could affect the results of the regression on panel data model. The VIF values also indicate absence of multicollinearity, since the highest VIF value found was 3,874 , and that only VIF values above 10 indicate problems of multicollinearity between the variables (Gujarati \& Porter, 2011). In this way, INC can be used together with the control variables to analyze the effects on the companies' performance.

Table 4 presents the panel data of the variables of accounting performance, from Return on Asset (ROA), Return on Capital Employed (ROCE) and Return on net Equity (ROE). 
Table 4. Panel data logistic regression of performance variables.

\begin{tabular}{|c|c|c|c|c|c|c|}
\hline \multirow{2}{*}{ Variables } & \multicolumn{2}{|c|}{ Model 1 - ROA } & \multicolumn{2}{|c|}{ Model 2 - ROCE } & \multicolumn{2}{|c|}{ Model 3 - ROE } \\
\hline & Coefficient & Sig. & Coefficient & Sig. & Coefficient & Sig. \\
\hline ROA & 0.675 & 0.002 & - & - & - & - \\
\hline ROCE & - & - & 0.018 & 0.006 & - & - \\
\hline ROE & - & - & - & - & 0.058 & 0.000 \\
\hline CSI & 3.838 & 0.000 & 3.465 & 0.000 & 3.864 & 0.000 \\
\hline GRO & $-4.51 \mathrm{E}-04$ & 0.379 & $-4.14 \mathrm{E}-04$ & 0.417 & $-7.36 \mathrm{E}-04$ & 0.160 \\
\hline TVD & -0.029 & 0.015 & -0.021 & 0.106 & -0.036 & 0.001 \\
\hline MV & 0.183 & 0.391 & 0.287 & 0.187 & 0.241 & 0.248 \\
\hline Log likelihood & -235.927 & & -234.795 & & -567.647 & \\
\hline \multirow[t]{2}{*}{ Qui-square } & $x^{2}=74.73$ & & $X^{2}=63.64$ & & $X^{2}=47.20$ & \\
\hline & \multicolumn{2}{|c|}{ Sig. $X^{2}=0.000$} & \multicolumn{2}{|c|}{ Sig. $X^{2}=0.000$} & \multicolumn{2}{|c|}{ Sig. $X^{2}=0.000$} \\
\hline Pseudo R2 of McFadden & \multicolumn{2}{|l|}{0.137} & \multicolumn{2}{|l|}{0.119} & \multicolumn{2}{|l|}{0.138} \\
\hline Pseudo R2 of Cox and Snell & \multicolumn{2}{|l|}{0.103} & \multicolumn{2}{|l|}{0.091} & \multicolumn{2}{|l|}{0.104} \\
\hline Pseudo R2 of Nagelkerke & \multicolumn{2}{|l|}{0.188} & \multicolumn{2}{|l|}{0.165} & \multicolumn{2}{|l|}{0.190} \\
\hline \multirow[t]{2}{*}{ Hausman } & \multicolumn{2}{|l|}{$X^{2}=25.68$} & \multicolumn{2}{|l|}{$X^{2}=30.39$} & \multicolumn{2}{|l|}{$x^{2}=27.64$} \\
\hline & \multicolumn{2}{|c|}{ Sig. $X^{2}=0.000$} & \multicolumn{2}{|c|}{ Sig. $X^{2}=0.000$} & \multicolumn{2}{|c|}{ Sig. $X^{2}=0.000$} \\
\hline
\end{tabular}

Source: Research data.

Table 4 shows that the Pseudo-R2 of Cox and Snell, Nagelkerke and McFadden provide weak explanatory power to the model, which should be considered as a limitation. Through the Hausman test, it was found out that the model of fixed effects is the best to be applied in the logistic regression of panel data. The Chi-square test was significant for the three models, a fact that contributes to the robustness of the data and the relationship investigated in this study.

The variables of accounting performance were significant with the INC, that is, the accounting performance of the companies is affected by the use of the INC. Regarding ROA, companies that use the INC tend to present a higher profit due to the efficiency of the application of resources. It is also verified that the decisions of the company to use the INC are relevant because, over time, a tendency of superior performance in the companies that use the INC has been observed. Levy (1990) points out that the use of fiscal policies of incentive for RD\&l increases private productivity. The use of the INC has the capacity of reducing the cost of capital for RD\&I, with a significant effect on the companies' decisions to invest, as indicated in the coefficients estimated by Model 1.

As for ROCE, the positive and significant effect of the use of the INC shows that the resources invested by the companies behave efficiently and the indicator is higher in the companies that use the benefit. The use of the INC can be considered a competitive advantage because it presents itself as a positioning attribute, external to the company, derived from the industry structure and the dynamics of governmental policies (Vasconcelos \& Cyrino, 2000).

The positive and significant effect of the use of the INC, regarding ROE, indicates that the adoption of fiscal policies of incentive for RD\&I generates positive returns on net equity. In this sense, the results of the research reveal that, of the companies surveyed, those that made use of the incentives of the Law of Good achieved superior performance regarding the return on the own resources invested by the shareholders of the companies. 
Table 5 presents the panel data of market performance variables, represented by Market-to-Book (MTB) and Tobin's Q (Q). In addition, the model is composed of the variable INC, which is the variable of interest, and the control variables Company Size (CSI), Growth Opportunity (GRO), Total Book Value of Debt (TVD).

Table 5. Panel data logistic regression of market performance variables.

\begin{tabular}{|c|c|c|c|c|}
\hline \multirow{2}{*}{ Variables } & \multicolumn{2}{|c|}{ Model 4 - MTB } & \multicolumn{2}{|c|}{ Model 5 - Tobin's Q } \\
\hline & Coefficient & Sig. & Coefficient & Sig. \\
\hline MTB & -0.042 & 0.428 & - & - \\
\hline Tobin's Q & - & - & -0.002 & 0.164 \\
\hline CSI & 3.453 & 0.000 & 3.466 & 0.000 \\
\hline GRO & $-2.28 \mathrm{E}-04$ & 0.674 & $-4.79 \mathrm{E}-04$ & 0.350 \\
\hline TVD & -0.030 & 0.038 & -0.016 & 0.225 \\
\hline MV & 0.559 & 0.036 & 0.399 & 0.047 \\
\hline Log likelihood & -185.158 & & -243.980 & \\
\hline \multirow[t]{2}{*}{ Qui-square } & $x^{2}=52.11$ & & $x^{2}=62.52$ & \\
\hline & Sig. $X^{2}=0.000$ & & Sig. $X^{2}=0.000$ & \\
\hline Pseudo $R^{2}$ of $M c F a d d e n$ & 0.123 & & 0.119 & \\
\hline Pseudo $R^{2}$ of Cox and Snell & 0.095 & & 0.091 & \\
\hline Pseudo $R^{2}$ of Nagelkerke & 0.171 & & 0.165 & \\
\hline \multirow[t]{2}{*}{ Hausman } & $x^{2}=23.26$ & & $X^{2}=27.28$ & \\
\hline & Sig. $X^{2}=0.000$ & & Sig. $X^{2}=0.000$ & \\
\hline
\end{tabular}

Source: Research data.

It can be seen in Table 5 that the technique that best applies to the models is that of fixed effects. Firstly, the Chi-square test is verified, which indicates that all the coefficients in the model are different from zero, reinforcing the quality of the data and the relationship among the variables. The coefficients of determination (Pseudo R2) have little ability to explain the data collected for the models, so the results should be observed with parsimony.

The market performance variables were not significant, that is, the companies' adoption of the incentives of the Law of Good was not reflected in high or low MTB and Tobin's $Q$. These findings reveal that the governmental actions and the companies' posture to make their RD\&I practices less expensive are still not captured by the market, perhaps due to the difficulty of their measurement and identification. Despite the time the Law has been in force, legal and political insecurities are still there, which may have influenced the shareholders, in general, to consider the INC as a risky investment that would question their future economic benefits (Georghiou et al., 2014).

Georghiou et al. (2014) argue that the INC instruments focus on the acquisition act and operational expenses and, at times, do not engage in the entire cycle of identifying the need for adoption and diffusion of innovation, although there are several barriers to reach this stage, and it generally involves a broader set of actors and stakeholders. Another argument involving INC and market performance variables regards the influence of the support offered by INC on the price of inputs of RD\&I, which are inelastic over time. It can be expected that RD\&l policies increase the demand for inputs of this nature, which implies in increasing RD\&I costs, thus reducing the return on investment (Montmartin \& Herrera, 2015). 
The findings of the research contribute to other studies that investigated the Law of Good, such as those of Formigoni et al. (2015), Chaves \& Costa (2016), Oliveira et al. (2017) and Zittei et al. (2016). Although correlated researches have not analyzed the effects of adopting the use of INC on market and accounting performance, they contribute to the findings of this study.

Formigoni et al. (2015) analyzed the relationship between the Fiscal Policy of Incentive for innovation (INC) and the generation of wealth created by the non-financial public companies. They found out that the companies that participate in INC tend to have a higher added value than those that do not participate. Thus, obtaining fiscal incentives by the Law of Good generates greater wealth for these companies in comparison to the others.

Chaves \& Costa (2016) verified the influence of the use of the Law of Good on the profitability of the companies listed in BM\&FBovespa. The results pointed out that the transfer of values from the government to the companies through the Law of Good has drawn positive results in the economic performance, meeting the proposed objectives. Therefore, this incentive, besides benefiting the increase of the competitive advantages of the companies within the market, contributes to the economic development of the country.

Oliveira et al. (2017) identified the reasons for companies of the Novo Mercado (New Market) not using fiscal incentives to technological innovation of the Law of Good. According to the authors, companies that invested in R\&D and do not use the Law of Good were not benefited due to having fiscal problems or having closed the fiscal year with loss. Thus, it can be seen that companies that adopt the Law of Good, commonly, do not have fiscal problems and have a profit in their fiscal years.

Zittei et al. (2016) have identified a correlation between the incentive for technological innovation (Law of Good) and the index of the global competitiveness of the nations, that is, as the number of companies that use the fiscal benefit increases, the index of global competitiveness from the country also increases. However, according to the authors, although the number of companies that use the benefit grows annually, few are able to adhere to this benefit due to the limitations imposed by the Law of Good.

Based on the results presented by the previous models and studies, it is believed that the effectiveness of the use of the Fiscal Policy of Incentive for Innovation (INC) improves the corporate performance and the economic environment by allowing companies to deduct investments in RD\&I and, thus, increase their RD\&I spending and, consequently, may contribute to the economic growth of the country.

\section{Conclusion}

This objective of this study was to analyze the effects of the use of the fiscal policy of incentive for innovation in the performance of Brazilian companies listed in Brazil Bolsa Balcão (B3), from 2006 to 2014. The results of the research showed that the fiscal policy of incentive for innovation contributed to the development of companies, by encouraging them to invest in RD\&I and to mitigate technological risks. The analysis of the period that the Law has been in force reveals that it has a potential impact on the creation of an innovative environment and on the ability of companies to receive external and internal investments for technological innovations in order to subsidize the supply chain and serve the consumers. 
Regarding the accounting performance of the companies analyzed, there is evidence that the companies' use of the fiscal policy of incentive for innovation is reflected in the superior performance of the resources employed (ROCE), its assets (ROA) and resources invested by the shareholders (ROE), which is characterized as a competitive advantage, considering the significance among the relations. This suggests that there is a significant and positive dependence of the companies in terms of the value and intensity of the use of the fiscal policies, with strong repercussions between private and public spending in RD\&I. Regarding the fiscal policy of incentive for innovation, it can cause a substitution effect between internal policies of RD\&I and external initiatives (Montmartin \& Herrera, 2015).

As for market performance, it was not found empirical evidence that the fiscal policy of incentive for innovation reflects in the market performance of the companies surveyed. This may indicate that the legal uncertainty and vulnerability of the legal aspects surrounding the Law are not yet clear to the market. Thus, it creates a favorable scenario to the improvement of the premises inherent in the Law of Good, and to an alignment in the interpretation of the Law and its application in the companies. The Law of Good can contribute to the repositioning of RD\&l assets in the companies, that is, the fiscal policy can foster the acquisition and manufacture of new industrial goods.

Regarding the role of government in the development of fiscal policies of incentive for innovation and the fostering of private sector spending on RD\&I, the study offers insights that there is a need to consider the existing interdependence within the national innovation system, in defining these policies. In the short term, these policies are proving to be efficient, but this may change in the long term, in spite of existing a tendency for companies to increase their RD\&l spending and the policy be characterized as efficient, or yet, companies can adopt a posture of replacing their investments in RD\&l by fiscal policies of incentive for innovation, which would characterize an inefficient fiscal policy.

In turn, companies need to realize that fiscal policies of incentive for innovation are palliative measures aimed at boosting and improving technological innovation, and that it is up to the companies to reinvent themselves in order to justify the use of fiscal policies of incentive for innovation. The aim is to increase investments in RD\&l and, as a counterpart to the government, reduce the tax burden, thus recognizing the importance of innovating for the companies to gain competitive advantage and indirectly for the country's growth.

The limitations imposed to the study represent gaps to be explored in other studies. In this sense, it is recommended an in-depth research on the companies that use these benefits and verify the perception regarding the use of the fiscal policy of incentive for innovation. Such research may represent a contribution to the empirical findings listed in this study. Another possibility is to verify the relationship between the use of the fiscal policy of innovation and the level of spending that companies destined to such practice, which can contribute to analyze the efficiency of the policy and also the companies' posture regarding its use.

\section{References}

Araújo, B. C. (2010). Incentivos fiscais à pesquisa e desenvolvimento e custos de inovação no Brasil. Brasília, DF: IPEA. Retrieved in 2017, February 16, from http://repositorio.ipea.gov.br/bitstream/11058/6761/1/Radar_n9_Incentivos.pdf 
Associação Nacional de Pesquisa e Desenvolvimento das Empresas Inovadoras - ANPEl. (2010). Guia prático de apoio à inovação: onde e como conseguir apoio para promover a inovação em sua empresa. Brasília: ANPEI.

Banco Interamericano de Desenvolvimento - IDB. (2014). ¿Cómo repensar el desarrollo productivo? Retrieved in 2017, February 16, from http://www.iadb.org/document.cfm?pubDetail=1\&id=39044963

Brasil. (1988, 20 de maio). Lei $n^{\circ} 2.433$, de 19 de maio de 1988. Dispõe sobre os instrumentos financeiros relativos à política industrial, seus objetivos, revoga incentivos fiscais e dá outras providências. Brasília, DF: Diário Oficial da República Federativa do Brasil.

Brasil. (1993, 3 de junho). Lei $n^{\circ}$ 8.661, de 2 de junho de 1993. Dispõe sobre os instrumentos financeiros relativos à política industrial, seus objetivos, revoga incentivos fiscais e dá outras providências. Brasília, DF: Diário Oficial da República Federativa do Brasil.

Brasil. (2005, 22 de novembro). Lei no 11.196, de 21 de novembro de 2005. Institui o Regime Especial de Tributação para a Plataforma de Exportação de Serviços de Tecnologia da Informação - REPES, o Regime Especial de Aquisição de Bens de Capital para Empresas Exportadoras - RECAP e o Programa de Inclusão Digital; dispõe sobre incentivos fiscais para a inovação tecnológica; altera o Decreto-Lei $n^{\circ} 288$, de 28 de fevereiro de 1967, o Decreto $n^{\circ} 70.235$, de 6 de março de 1972, o Decreto-Lei no 2.287, de 23 de julho de 1986, as Leis $n^{\circ}$ S 4.502, de 30 de novembro de 1964, 8.212, de 24 de julho de 1991, 8.245, de 18 de outubro de 1991, 8.387, de 30 de dezembro de 1991, 8.666, de 21 de junho de 1993, 8.981, de 20 de janeiro de 1995, 8.987, de 13 de fevereiro de 1995, 8.989, de 24 de fevereiro de 1995, 9.249, de 26 de dezembro de 1995, 9.250, de 26 de dezembro de 1995, 9.311, de 24 de outubro de 1996, 9.317, de 5 de dezembro de 1996, 9.430, de 27 de dezembro de 1996, 9.718, de 27 de novembro de 1998, 10.336, de 19 de dezembro de 2001, 10.438, de 26 de abril de 2002, 10.485, de 3 de julho de 2002, 10.637, de 30 de dezembro de 2002, 10.755, de 3 de novembro de 2003, 10.833, de 29 de dezembro de 2003, 10.865, de 30 de abril de 2004, 10.925, de 23 de julho de 2004, 10.931, de 2 de agosto de 2004, 11.033, de 21 de dezembro de 2004, 11.051, de 29 de dezembro de 2004, 11.053, de 29 de dezembro de 2004, 11.101, de 9 de fevereiro de 2005, 11.128, de 28 de junho de 2005, e a Medida Provisória $n^{\circ}$ 2.199-14, de 24 de agosto de 2001; revoga a Lei $n^{\circ} 8.661$, de 2 de junho de 1993, e dispositivos das Leis $n^{\circ}$ s 8.668, de 25 de junho de 1993, 8.981, de 20 de janeiro de 1995, 10.637, de 30 de dezembro de 2002, 10.755, de 3 de novembro de 2003, 10.865, de 30 de abril de 2004, 10.931, de 2 de agosto de 2004, e da Medida Provisória $n^{\circ}$ 2.158-35, de 24 de agosto de 2001; e dá outras providências. Brasília, DF: Diário Oficial da República Federativa do Brasil.

Brasil. (2006, 8 de junho). Decreto $n^{\circ} 5.798$, de 7 de junho de 2006. Regulamenta os incentivos fiscais às atividades de pesquisa tecnológica e desenvolvimento de inovação tecnológica, de que tratam os arts. 17 a 26 da Lei $n^{\circ}$ 11.196, de 21 de novembro de 2005. Brasília, DF: Diário Oficial da República Federativa do Brasil.

Brasil. (2007, 15 de maio). Lei no 11.487, de 15 de junho de 2007. Altera a Lei no 11.196, de 21 de novembro de 2005, para incluir novo incentivo à inovação tecnológica e modificar as regras relativas à amortização acelerada para investimentos vinculados a pesquisa e ao desenvolvimento. Brasília, DF: Diário Oficial da República Federativa do Brasil.

Brasil. (2011, 29 de agosto). Instrução normativa RFB no 1.187, de 29 de agosto de 2011. Disciplina os incentivos fiscais às atividades de pesquisa tecnológica e desenvolvimento de inovação tecnológica de que tratam os arts. 17 a 26 da Lei $n^{\circ} 11.196$, de 21 de novembro de 2005. Brasília, DF: Diário Oficial da República Federativa do Brasil.

Brasil. Ministério da Ciência, Tecnologia e Inovação. (2015). Relatório anual da utilização dos incentivos fiscais - ano base 2014. Retrieved in 2017, February 16, from http://www.mct.gov.br

Calmanovici, C. E. (2011). A inovação, a competitividade e a projeção mundial das empresas brasileiras. Revista USP, 89, 190-203. https://doi.org/10.11606/issn.2316-9036.v0i89p190203. 
Chaves, S. K. (2016). O impacto da Lei do Bem sobre o desempenho econômico de empresas de capital aberto. (Dissertação de mestrado). Universidade do Vale do Rio do Sinos, São Leopoldo.

Chaves, S. K., \& Costa, C. M. (2016). O impacto da Lei do Bem sobre o desempenho financeiro de empresas de capital aberto. In Anais do $10^{\circ}$ Congresso da Associação Nacional de Programas de Pós-Graduação em Ciências Contábeis, Rsão Leopoldo: UNISINOS.

David, P. A., Hall, B. H., \& Toole, A. A. (2000). Is public R\&D a complement or substitute for private R\&D? A review of the econometric evidence. Research Policy, 29(4), 497-529. http://dx.doi.org/10.1016/S0048-7333(99)00087-6.

Fávero, L. P. (2015). Análise de dados: modelos de regressão com EXCEL ${ }^{\circledR}, S_{T A T A}{ }^{\circledR} e$ SPSS ${ }^{\circledR}$. São Paulo: Atlas.

Formigoni, H., Carneiro, M. I. V., Gomes, M. E. R., \& Segura, L. C. (2015). A relação entre os incentivos fiscais da Lei do Bem (PDTI) e a geração de riqueza pelas companhias abertas brasileiras. Contabilometria, 2(1), 1-14.

Garcia, C., \& Bicalho, T. (2014). Histórico dos mecanismos de apoio por meios dos incentivos fiscais. In C. Garcia (Org.), Lei do Bem: como alavancar a inovação com a utilização dos incentivos fiscais. São Paulo: Ed. Pillares.

Georghiou, L., Edler, J., Uyarra, E., \& Yeow, J. (2014). Policy instruments for public procurement of innovation: Choice, design and assessment. Technological Forecasting and Social Change, 86, 1-12. http://dx.doi.org/10.1016/j.techfore.2013.09.018.

Gujarati, D. N., \& Porter, D. C. (2011). Econometria básica (5. ed.). São Paulo: McGraw-Hill.

Kim, W. S., \& Yun, K. Y. (1988). Fiscal policy and development in Korea. World Development, 16(1), 65-83. http://dx.doi.org/10.1016/0305-750X(88)90164-7.

Levy, D. M. (1990). Estimating the impact of government R\&D. Economics Letters, 32(2), 169173. http://dx.doi.org/10.1016/0165-1765(90)90072-9.

Lopes, I. F., \& Beuren, I. M. (2016). Evidenciação da Inovação no Relatório da Administração: uma análise na perspectiva da Lei do Bem (Lei №. 11.196/2005). Perspectivas em Gestão \& Conhecimento, 6(1), 109-127.

Lopes, I. F., Beuren, I. M., \& Dametto, I. D. R. B. (2016). Evidenciação dos recursos aplicados em pesquisa, desenvolvimento \& inovação e da redução de carga tributária por empresas listadas na BM\&FBovespa. ConTexto, 16(32), 53-76.

Mendes, D. R. F., Oliveira, M. Â. C., \& Pinheiro, A. A. (2013). Política Nacional de Ciência, Tecnologia e Inovação: avaliação do marco regulatório e seus impactos nos indicadores de inovação. Revista de Empreendedorismo e Gestão de Pequenas Empresas, 2(1), 2246. http://dx.doi.org/10.14211/regepe.v2i1.49.

Montmartin, B., \& Herrera, M. (2015). Internal and external effects of R\&D subsidies and fiscal incentives: empirical evidence using spatial dynamic panel models. Research Policy, 44(5), 1065-1079. http://dx.doi.org/10.1016/j.respol.2014.11.013.

Oliveira, O., Zaba, E., \& Forte, S. (2017). Razão da não utilização de incentivos fiscais à inovação tecnológica da Lei do Bem por empresas brasileiras. Revista Contemporânea de Contabilidade, 14(31), 67-88. http://dx.doi.org/10.5007/2175-8069.2017v14n31p67.

Organization for Economic Co-operation and Development - OECD. (2013). Manual de Frascati: metodologia proposta para levantamentos sobre pesquisa e desenvolvimento experimental. Retrieved in 2017, February 16, from http://www.finiciativas.com.br/sites/default/files/Manual-de-Frascati.pdf

Oyadomari, J. C. T., Cardoso, R. L., Silva, B. O. T., \& Perez, G. (2010). Sistemas de controle gerencial: estudo de caso comparativo em empresas inovadoras no Brasil. Revista Universo Contábil, 6(4), 21-34. http://dx.doi.org/10.4270/ruc.2010429. 
Piva, S. H. (2013). Os incentivos fiscais às atividades de pesquisa e desenvolvimento de inovação tecnológica. São Paulo: FISCOSoft.

Schumpeter, J. A. (1961). Teoria do desenvolvimento econômico. Rio de Janeiro: Editora Fundo de Cultura.

Silva, C. G., \& Terra, F. H. B. (2012). O desempenho econômico brasileiro em 2011 e perspectivas para 2012: uma análise rápida em um período complexo. Revista Economia \& Tecnologia, 8(1), 7-17. http://dx.doi.org/10.5380/ret.v8i1.27590.

Soly, B., Paixão, F., Tavares, L., Azevedo, P., \& Souza, P. (2014). Os incentivos fiscais à inovação tecnológica. In C. Garcia (Org.), Lei do Bem: como alavancar a inovação com a utilização de incentivos fiscais. São Paulo: Ed. Pillares.

Vasconcelos, F. C., \& Cyrino, A. B. (2000). Vantagem competitiva: os modelos teóricos atuais e a convergência entre estratégia e teoria organizacional. Revista de Administração de Empresas, 40(4), 20-37. http://dx.doi.org/10.1590/S0034-75902000000400003.

Zittei, M. V. M., Lugoboni, L. F., Rodrigues, A. D. L., \& Chiarello, T. C. (2016). Lei do Bem: o incentivo da inovação tecnológica como aumento da competitividade global do Brasil. Gestão, Inovação e Tecnologias, 6(1), 2925-2943. http://dx.doi.org/10.7198/S22370722201600010015. 